\title{
Sarcomatoid Adenocarcinoma of the Ampulla of Vater
}

\author{
Jae Hag Jung ${ }^{1}$ Y Yun Su Mun ${ }^{1}$ \\ Received: 5 December 2017 / Accepted: 28 March 2018 / Published online: 7 April 2018 \\ (C) Indian Association of Surgical Oncology 2018
}

\begin{abstract}
Sarcomatoid adenocarcinoma of ampulla of Vater is an extremely rare malignant neoplasm that displays both carcinomatous and sarcomatous component. A 58-year-old woman was admitted to our hospital under the suspicion of an ampulla of Vater cancer. Abdominal computed tomography and endoscopy demonstrated a bulging of ampulla and the biopsy specimen revealed an adenocarcinoma, well differentiated in the background of tubulovillous adenoma. So we performed the pylorus preserving pancreaticoduodenectomy. At postoperative biopsy, the tumor was composed of adenocarcinoma component and sarcomatoid component. Thus, a diagnosis of sarcomatoid adenocarcinoma of ampulla of Vater could be made. Here, we present a case of sarcomatoid adenocarcinoma of ampulla of Vater.
\end{abstract}

Keywords Sarcomatoid adenocarcinoma A Ampulla of Vater

\section{Introduction}

Sarcomatoid adenocarcinomas are composed of the two cell populations, a sarcomatous component and a carcinomatous component. Among the sarcomatoid adenocarcinomas, sarcomatoid adenocarcinoma of ampulla of Vater is an extremely rare malignant neoplasm. We herein present a case of sarcomatoid adenocarcinoma of ampulla of Vater.

\section{Case Report}

A 58-year-old woman was admitted to our hospital under the suspicion of an ampulla of Vater cancer. Her medical history was non-specific, except diabetes. Routine laboratory data were all within the normal ranges. Serum alpha fetoprotein (AFP) and carbohydrate antigen 19-9 levels were $1.3 \mathrm{ng} / \mathrm{ml}$ (reference range $<8.1 \mathrm{ng} / \mathrm{ml}$ ) and $495.8 \mathrm{U} / \mathrm{ml}$ (reference range $<35 \mathrm{IU} / \mathrm{ml}$ ), respectively. Abdominal computed tomography from the local clinic showed dilatation of both intra-hepatic duct and common bile duct (CBD) with about $0.8 \mathrm{~cm}$ short segmental circumferential mural thickening with luminal

Yun Su Mun

mdearnest@naver.com

1 Department of Surgery, Eulji University Hospital, 95 Dunsanseo-ro, Daejeon, Seo-gu 302-799, Korea narrowing of distal CBD (Fig. 1a, b). Positron emission tomography (PET-CT) scan revealed a hypermetabolic mass in distal CBD (Fig. 1c). Endoscopy performed our hospital demonstrated a bulging of ampulla and biopsy was performed (Fig. 1d). A biopsy specimen revealed an adenocarcinoma, well differentiated in the background of tubulovillous adenoma. We performed the pylorus-preserving pancreaticoduodenectomy.

Macroscopically, there was an ill-defined mass measuring $10 \times 6 \mathrm{~mm}$ at the ampulla of Vater. Microscopically, the tumor was composed of adenocarcinoma component and sarcomatoid component (Fig. 2a, b). The primary tumor invades duodenal wall. (T2) Microscopic lymph node metastases with adenocarcinoma cells were not seen in the regional lymph node. (N0) On immunohistochemistry, CK7, vimentin, EMA, and CK were expressed (Fig. 2c, d, e, f). Thus, a diagnosis of sarcomatoid adenocarcinoma of ampulla of Vater could be made. The patient's postoperative course was uneventful, except intra-abdominal abscess. She was discharged 49 days after the operation. Our patient has been living well without recurrence for 14 months after surgery.

\section{Discussion}

Sarcomatoid adenocarcinomas are extremely rare malignant neoplasms that display both malignant epithelial and stromal component [1]. These tumors have been found in the lungs, 
Fig. 1 a, b Initial abdominal computed tomography scan showed dilatation of both IHD \& CBD with about $0.8 \mathrm{~cm}$ short segmental circumferential mural thickening with luminal narrowing of distal CBD (arrow). c Positron emission tomography scan revealed an hypermetabolic mass in distal CBD (arrow). d Endoscopy performed our hospital demonstrated a bulging of ampulla and biopsy was performed
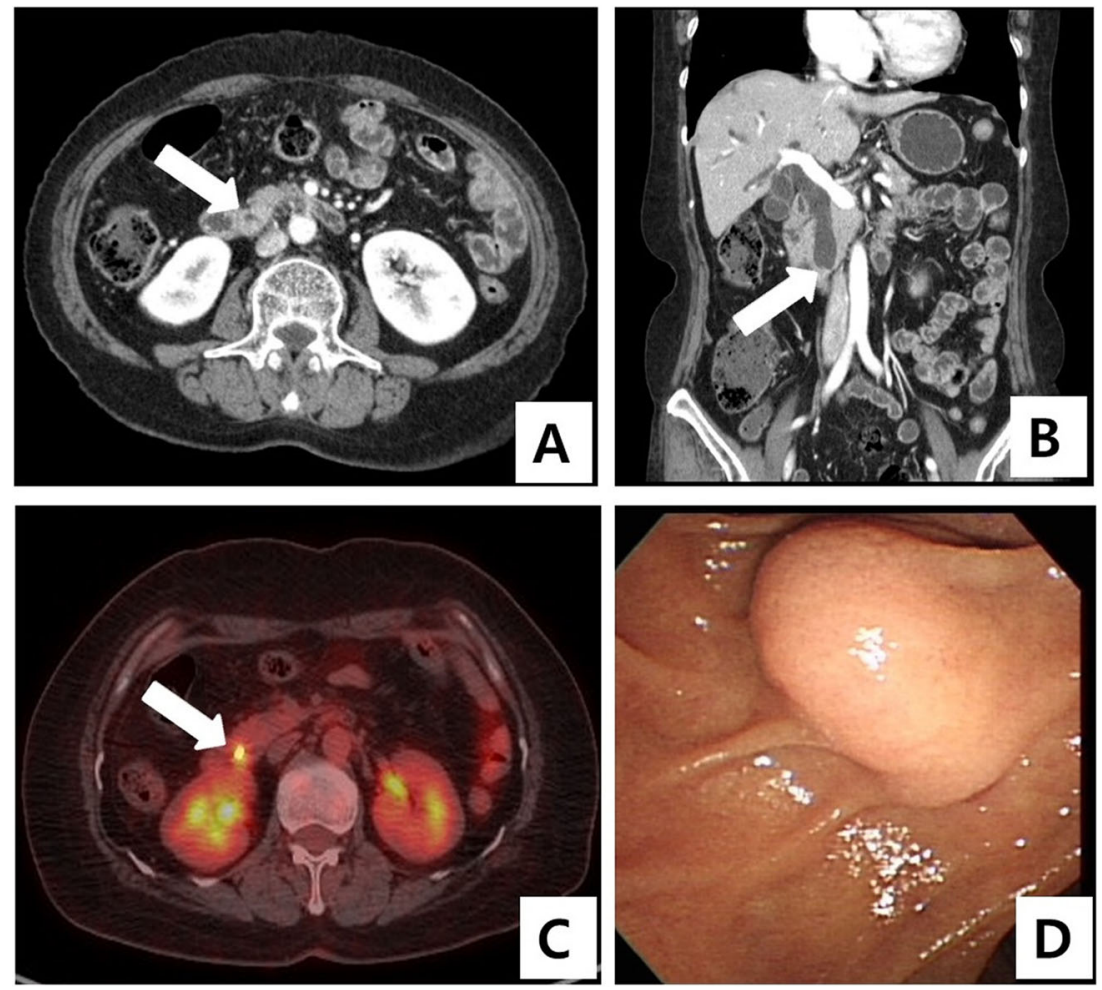

skin, thymus, and digestive tract [2-4]. They are also found in the gastrointestinal tract, but published reports about sarcomatoid adenocarcinoma of ampulla of Vater are rare. MEDLINE search revealed only three case report historically defined sarcomatoid adenocarcinoma of ampulla of Vater cases reported in the literature from 1997 to the present [5-7]. And the first report was described by Kench in 1997 (Table 1).

In our present case, the biopsy specimen from the endoscopy of the upper gastrointestinal tract showed that the lesion was an adenocarcinoma, well differentiated in the background of tubulovillous adenoma. But at postoperative biopsy, the tumor was composed of adenocarcinoma component and sarcomatoid component, microscopically. The tumor was finally diagnosed as sarcomatoid carcinoma, since the immunohistochemical analysis was positive for carcinomatous elements (keratin, EMA, and CA 19-9) and sarcomatous elements (vimetin and SMA). For a conventional microscopic diagnosis, the presence of a transitional zone and genuine sarcomatous components are key points [1]. Table 1 shows the characteristics of our case and the three previously reported cases of sarcomatoid carcinoma of ampulla of Vater. The age of the patients ranged from 46 to 70 years (mean 55). A surgical resection was performed in all cases.

There are many theories that have been proposed for the pathogenesis of sarcomatoid adenocarcinomas [8]. The first theory is that multipotential cells, such as stem cells, may become malignant and differentiate into the sarcomatoid and epithelial elements. The second is that two individual stem cells may independently and simultaneously undergo malignant transformation to thereafter become separate tumors (true sarcomatoid adenocarcinomas). The third is that cancer cells can cause anaplasia in immature cells, which have the characteristics of both epithelial and mesenchymal elements.

Previously reported cases of sarcomatoid carcinoma of ampulla of Vater and sarcomatoid carcinoma in other digestive organ have been reported with poor prognosis [5-7, 9]. Like the sarcomatoid adenocarcinoma of the Ampulla of Vater, it occurs rarely in the pancreas head and the prognosis is poor [10]. Majority of the malignant tumors of the duodenum were treated by the pancreatoduodenectomy with regional lymph node dissection. In this case, pylous-preserving pancreatoduodenectomy and a resection of the para-aortic lymph nodes were performed. Some cases of the primary duodenal adenocarcinoma have been treated with a chemotherapy has been reported [11]. But the current patient received no adjuvant chemotherapy because of the non-advanced status of disease. 5-Fluorouracil has been used for more than 40 years for the treatment of diverse tumors and it remains a standard first-line chemotherapy for gastrointestinal cancers (adenocarcinoma). However, the efficacy of chemotherapy for duodenal cancer still remains unclear. More cases must therefore be observed to establish the optimal treatment for sarcomatoid carcinoma of ampulla of Vater. 
Fig. 2 The microscopic findings and immunohistochemical staining of the tumor a The microscopic findings of the resected specimen ( $\mathrm{H}$ and $\mathrm{E}$ stain, $\times 200$ ). The subserous layer had been invaded by the tumor cells. b The microscopic findings of the resected specimen (H and $\mathrm{E}$ stain, $\times 400$ ) showing the presence of adenocarcinoma component and sarcomatoid component. The immunohistochemical staining of the tumor. Sarcomatoid carcinoma of the ampulla of Vater. Positive staining for $\mathrm{CK}(\times$ $400, \mathbf{c}), \operatorname{CK} 7(\times 400, \mathbf{d}), \operatorname{EMA}(\times$ $400, \mathbf{e})$, and vimetin $(\times 400, \mathbf{f})$ were expressed
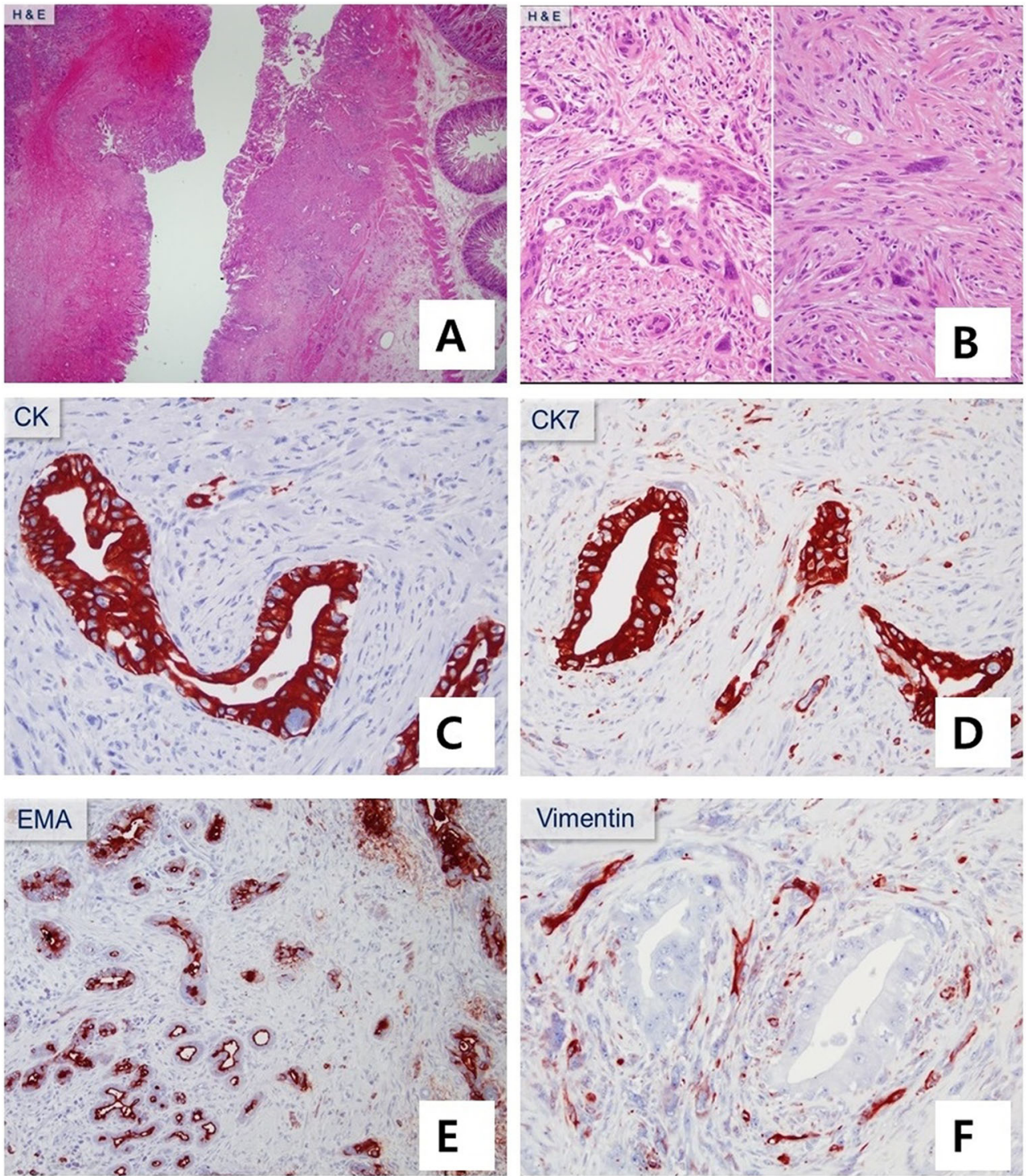

Table 1 Reported cases of sarcomatoid carcinoma of ampulla of Vater

\begin{tabular}{|c|c|c|c|c|c|c|c|c|c|}
\hline Author & Years & Age & Sex & Location & $\begin{array}{l}\text { Size } \\
(\mathrm{mm})\end{array}$ & $\begin{array}{l}\text { Gross } \\
\text { features of } \\
\text { the tumor }\end{array}$ & Component & Treatment & Prognosis \\
\hline Kench & 1997 & 46 & $\mathrm{~F}$ & $\begin{array}{l}\text { On the } \\
\text { ampulla } \\
\text { of Vater }\end{array}$ & & & $\begin{array}{l}\text { Adenocarcinoma cells, squamous } \\
\text { carcinoma cells, and spindle-type } \\
\text { sarcoma cells (so-called) }\end{array}$ & Pancreatoduodenectomy & $\begin{array}{l}\text { Expire } \\
\qquad(8 \text { months })\end{array}$ \\
\hline Kijima & 1999 & 46 & M & $\begin{array}{l}\text { On the } \\
\text { ampulla } \\
\text { of Vater }\end{array}$ & & $\begin{array}{l}\text { Ulcerating } \\
\text { tumor }\end{array}$ & $\begin{array}{l}\text { Adenocarcinoma cell and } \\
\text { spindle-type sarcoma cells } \\
\text { (so-called) }\end{array}$ & Pancreatoduodenectomy & Unknown \\
\hline Tanaka & 2008 & 70 & $\mathrm{~F}$ & $\begin{array}{l}\text { On the } \\
\text { ampulla } \\
\text { of Vater }\end{array}$ & $24 \times 15$ & $\begin{array}{l}\text { Nodular and } \\
\text { polypoid } \\
\text { tumor }\end{array}$ & $\begin{array}{l}\text { Adenocarcinoma cell and } \\
\text { spindle-type sarcoma cells (pure) }\end{array}$ & $\begin{array}{l}\text { Pylorus-preserving } \\
\text { pancreaticoduodenectomy }\end{array}$ & $\begin{array}{l}\text { Alive } \\
\qquad(24 \text { months })\end{array}$ \\
\hline $\begin{array}{c}\text { Present } \\
\text { case }\end{array}$ & 2014 & 58 & $\mathrm{~F}$ & $\begin{array}{l}\text { On the } \\
\text { ampulla } \\
\text { of Vater }\end{array}$ & $10 \times 6$ & $\begin{array}{l}\text { Ill defined, } \\
\text { infiltrative }\end{array}$ & $\begin{array}{l}\text { Adenocarcinoma cell and } \\
\text { spindle-type sarcoma cells (pure) }\end{array}$ & $\begin{array}{l}\text { Pylorus-preserving } \\
\text { pancreaticoduodenectomy }\end{array}$ & $\begin{array}{l}\text { Alive } \\
\qquad(17 \text { months })\end{array}$ \\
\hline
\end{tabular}




\section{Conclusion}

This is the first report of sarcomatoid adenocarcinoma of ampulla of Vater in Korea. As the sarcomatoid adenocarcinoma of ampulla of Vater demonstrates highly aggressive behavior and the efficacy of other modalities of treatment is currently unclear, radical surgery and short-term follow-up are recommended.

Conflicts of Interest The authors declare that they have no conflict of interest.

\section{References}

1. Rosai J (2011) Rosai and Ackerman's surgical pathology, 10th edn. Mosby, Edinburgh

2. Inomata M, Kawagishi Y, Yamada T et al (2010) Two cases of pulmonary sarcomatoid carcinoma mimicking malignant mesothelioma. Nihon Kokyouki Gakkai Zasshi 48(1):33-38

3. Rios-Martin JJ, Parra-Martin JA, Gomez-Pascual A, HeviaVazquez A, Gonzalez-Campora R (1998) Sarcomatoid carcinoma of the skin: report of a case. J Dermatol 25(5):314-321
4. Moritani S, Ichihara S, Mukai K, Seki Y, Inoue S, Yasuda A, Hakiri S, Yatabe Y, Eimoto T (2008) Sarcomatoid carcinoma of the thymus arising in metaplastic thymoma. Histopathology 52(3):409411

5. Kench JG, Frommer DJ (1997) Sarcomatoid carcinoma of the ampulla of Vater. Pathology 29(1):89-91

6. Kijima H, Takeshita T, Suzuki H, Tanahashi T, Suto A, Izumika H, Miki H, Terasaki Y, Nakamura M, Watanabe H, Tamaoki N, Omiya $\mathrm{H}$ (1999) Carcinosarcoma of the ampulla of Vater: a case report with immunohistochemical and ultrastructural studies. Am J Gastroenterol 94(10):3055-3059

7. Tanaka A, Hirabayashi K, Tobita K, Okamura T, Takashimizu S, Ishii M, Dowaki S, Yasuda M, Mine T, Ogoshi K, Imaizumi T, Makuuchi H (2008) Carcinosarcoma of the ampulla of Vater. J Clin Gastroenterol 42(7):864-865

8. Takao S, Takada N, Watanabe J, Kuniyoshi M, Satoh T (2008) A case of sarcomatoid carcinoma of the liver. Kanzo 49:376-385

9. Sasajima K, Taniguchi Y, Morino K et al (1988) Rapid growth of a pseudosarcoma of the esophagus. J Clin Gastroenterol 105:533536

10. Jia Z, Zhang K, Huang R, Zhou X, Jiang L (2017 Jan) Pancreatic carcinosarcoma with rare long term survival. Medicine (Baltimore) 96(4):e5766

11. Sunagawa $H$, Inamine $S$, Watanabe $M$, Kawakami K, Toyama $T$, Zaha H, Yonaha T, Ohta M, Oshiro N, Takeshima M, Uchima H (2009) Carcinosarcoma of the duodenum: report of a case. Surg Today 39(10):892-896 